\title{
EDUCATION AS HABILITATION: EMPIRICAL EXAMPLES FROM ADJUSTED EDUCATION IN SWEDEN FOR STUDENTS ASSOCIATED WITH HIGH-FUNCTIONING AUTISM ${ }^{1}$
}

\begin{abstract}
This article draws upon findings from an educational program in Information Technology for young adults associated with high-functioning autism. The aim of the program was to make the students employable. Data was collected through participant observation and research interviews. Of the twelve students who completed their education, five had made transitions to employment and three held internship places. Because of this training and the adaptations that were made within the educational program, the well-being of the students improved, and their need for home support and medication decreased. Important adjustments included the provision of individual work places, the clear structure of the work that was to be performed, and the creation of an environment where the students were seen, acknowledged, and understood.
\end{abstract}

Keywords: adjusted education, habilitation, high-functioning autism, interpersonal relations, social learning

\section{IZOBRAŽEVANIE KOT HABILITACIJA: EMPIRIČNI PRIMERI PRILAGOJENEGA IZOBRAŽEVANIA ZA UDELEŽENCE Z VISOKOFUNKCIONALNIM AVTIZMOM NA ŠVEDSKEM - POVZETEK}

Članek črpa iz ugotovitev izobraževalnega programa informacijske tehnologije za mlajše odrasle z visokofunkcionalnim avtizmom. Program je bil usmerjen $v$ zaposljivost udeležencev. Podatke smo zbrali s pomočjo opazovanja z udeležbo in raziskovalnih intervjujev. Med 12 udeleženci, ki so končali to

Martin Hugo, PhD, School of Education and Communication, Jönköping University, martin.hugo@ju.se

Joel Hedegaard, PhD, School of Education and Communication, Jönköping University, joel.hedegaard@ju.se

1 We would like to thank Professor Helene Ahl and Associate Professor Cecilia Bjursell of the National Centre for Lifelong Learning at Jönköping University for their comments on previous drafts of this paper. This article is part of a research project that is financed by Eksjö Municipality. 
izobraževanje, jih je pet prešlo v zaposlitev, trije pa so opravljali prakso. Usposabljanje in prilagoditve znotraj izobraževalnega programa so izboljšali počutje udeležencev, prav tako se je zmanjšala njihova potreba po podpori $v$ domačem okolju in po zdravilih. Med pomembnimi prilagoditvami so bili omogočenje individualnih delovnih prostorov, jasna struktura pričakovanih delovnih nalog in ustvarjanje okolja, kjer so bili udeleženci videni, upoštevani in razumljeni.

Ključne besede: prilagojeno izobraževanje, habilitacija, visokofunkcionalni avtizem, medosebni odnosi, socialno učenje

\section{INTRODUCTION}

The purpose of this article is to highlight empirical examples of habilitating effects from an adjusted education program within the field of Information Technology (IT) for young adults associated with high-functioning autism. Furthermore, our ambition was to allow the participants/students to describe their experience of the program in their own words.

People associated with different disabilities are, to a large extent, excluded from and even discriminated against in society. This can be observed in the context of school, health care, and in the labour market. Internationally, previous research shows that people associated with disabilities experience socio-economic hardship (Goodley, 2017; Houtenville, Brucker and Lauer, 2016), violation of rights (Lang, 2009; Meekosha and Soldatic, 2011; Priestley, 2007; World Health Organization and The World Bank, 2011) and a higher incidence of destructive lifestyles (for instance in terms of smoking and obesity) than those not associated with disabilities (Houtenville, Brucker and Lauer, 2016). The exclusion and discrimination of people associated with disabilities incurs considerable individual and societal costs. In the Swedish society, people associated with disabilities face great difficulties in getting a foothold in the labor market (Arbetsförmedlingen, 2015; Socialstyrelsen, 2012). Breaking down the alienation of people associated with disabilities so that they can find work in the regular labour market is a major challenge. Besides preventing individual stigmatization, breaking down this alienation is estimated to allow for social savings of between SEK 11-14 million (approximately USD 1.2-1-6 million) for each young individual that is subsequently included in society (Nilsson and Wadeskog, 2012). However, the group of persons with disabilities is very heterogeneous and there are wide variations in unemployment rates.

The increasingly deregulated labor market in Sweden has contributed to streamlining the process of working life with an increased work pace, upskilling, and slimmer organizations and businesses. These changes have primarily (negatively) affected the ability of vulnerable and marginalized groups to enter the labour market (Ahrne, Roman and Franzén, 2013). For people associated with neuropsychiatric disabilities this has been especially challenging - this group has the second lowest employment rate (Lindqvist, 2012). Furthermore, once they enter the labour market, they are four times more likely to be subjected to discrimination compared to the general population (Statistiska Centralbyrån, 2015). 
The situation is no different for people associated with high-functioning autism. Many of these individuals experience difficulties in obtaining a job, and keeping it (Hendricks, 2010; Krieger, Kinébanian, Prodinger and Heigl, 2012; Larsson Abbad, 2007; Roux et.al., 2013; Roy, 2015). It is estimated that between 10 and 15 percent of people associated with high-functioning autism were gainfully employed in Sweden in 2006 (Andersson, 2006). Even for individuals who have the training and skills required, it is a great challenge to be seen as 'employable' (Andersson, 2008), the reason being that people associated with high-functioning autism are seen as having poor social skills and lacking empathy and relationship building abilities (Attwood, 2008; Volkmar, Klin and McPartland, 2014; Wing, 1981).

For people with disabilities, the process of exclusion begins already during their early education. Previous research has shown that young people who have been diagnosed with high-functioning autism do not get their special needs met to the extent desired; this significantly impinges on their ability to do well at school (Attwood, 2008; Jackson, 2011; Simmeborn Fleischer, 2012). This may discourage participation in future education programs, since previously experienced failure reduces the tendency of people to engage in a similar activity (Bandura, 1982; Cron, Slocum, Vandevalle and Fu, 2005). As argued in Antonovsky's Sense of coherence (1987), people need to feel fulfillment in their encounters with the world of education and work so as to prevent new failures from occurring. People associated with high-functioning autism often need specially-designed support functions with respect to both formal and informal learning (Adolfsson and Simmeborn Fleischer, 2013; Anthony and Unger, 1991; Börnfelt, 2014; Giarelli and Fisher, 2013; Mowbray, 2000; Unger, Anthony, Sciarappa and Rogers, 1991). Consequently, students need to feel that their studies are meaningful, they understand the goal of their studies, and are able to cope with the educational challenges they face. This requires adapted teaching and effective support in order to prevent new failures, to build trust, and to strengthen the students' confidence in their studies (Aspelin, 2012; Hugo, 2007; 2013; Johnson, 2008).

This article reports on several findings from a unique Swedish IT education project called the IT-track for young adults associated with high-functioning autism. This project is an example of an initiative that was established with the intention of breaking down the isolation and exclusion that people associated with high-functioning autism are subject to, in favour of future inclusion. The set-up of the educational project with its various adjustments is in fact an example of an excluding (and exclusive) environment in that only students associated with high-functioning autism attend the program. So, it is a matter of inclusion through exclusion (Lozic, 2014); the exclusion precedes the inclusion. The aim of the IT-track is to offer students the specific educational conditions that will enable them to break their isolation and subsequently enter the labour market. It is an example of a habilitation project, since it concerns a group of participants/students in lack of previous experience of higher education and/or regular work after finishing upper secondary school, and who need to develop or gain certain skills (besides formal IT-skills) in order to become employable. The term habilitation is more suitable here than the term 
rehabilitation. The latter term would focus on the return to work after a period of absence and the re-gaining of certain skills that were temporarily lost.

The IT-track was founded by the European Social Fund (ESF), Region Jönköping, Höglandet's Coordinating Association and Eksjö Municipality, and started in January 2012 in Eksjö. The cost of the IT-track was approximately SEK 2 million per year (approximately USD 0.23 million). When the funding from the ESF ended in 2015, the other three financiers took over the funding responsibility. Region Jönköping, Höglandet's Coordinating Association, Finnvedens Coordinating Association and Södra Vätterbygdens Coordinating Association funded the IT-track in 2016 and 2017.

This educational program was made available to young people (19-30 years old) who were diagnosed with high-functioning autism. In addition to high-functioning autism, nine of the students also have additional diagnoses, such as schizophrenia, obsessive-compulsive disorder, and bipolar disorder.

The IT-track accommodates 15 students and offers upper secondary and university level courses in programming, $\mathrm{CAD}$, and computer systems, as well as an internship experience. On completing the courses, the students get formal upper secondary school grades. For the university courses they receive a non-formal certificate as they are not formally qualified to attend them. The following staff members support the students during their participation in the program; a head teacher (working full-time), a university teacher (working part-time), an occupational therapist/coordinator, a psychologist, a psychiatrist, and a contact person from the Employment Service. The head teacher is responsible for establishing and maintaining internship contacts and the occupational therapist/coordinator is responsible for contact with various authorities.

\section{METHODS}

The study is inspired by ethnographic methodology (Hammersley and Atkinson, 2007), where researchers reside within the environments and situations they want to learn about. We resided in the specific culture of the IT-track in order to gain knowledge about the students' lived experiences (Van Manen, 1990). According to Hammersley and Atkinson (2007), the actions of individuals can only be understood from within the context that they are situated in. By taking part in the practice, observing what happens, listening to what is said, and by asking questions, the researcher can come to an understanding of the participants' experiences and the learning that takes place in this context. The observations in this study were used to enable an understanding of the context, and they also helped us to get to know the prospective interviewees and to develop a trust-based relationship with them that subsequently enabled the interviews. The context of the present study was limited to the delivery of the IT-track in the autumn of 2014 and a follow up study in the autumn of 2016. 


\section{Data collection}

Data were collected in four ways: (a) participant observation and natural conversations (see Van Manen, 1990) in the autumn of 2014, (b) 14 research interviews with students, (c) one focus group interview with the staff, and (d) a follow up interview two years later with the occupational therapist/coordinator. Participant observation and natural conversations were conducted by the two researchers together. During the observation period, the experiences of the respondents were shared with the researchers during actual learning situations. Van Manen (1990) describes this approach as 'close observation', in which the researchers bridge the distance between the researcher and the participant(s) by entering the lifeworld of the participant(s). Research interviews were conducted with the students. Fourteen of the 15 students who were enrolled in the project during the autumn of 2014 took part in interviews that lasted between 20 and 60 minutes. The students are further described in Table 1 below:

Table 1: Overview of student characteristics

\begin{tabular}{|l|c|c|c|c|c|c|c|c|c|c|c|c|c|c|}
\hline Respondents & 1 & 2 & 3 & 4 & 5 & 6 & 7 & 8 & 9 & 10 & 11 & 12 & 13 & 14 \\
\hline Age & 26 & 27 & 25 & 26 & 29 & 27 & 29 & 26 & 25 & 22 & 22 & 30 & 21 & 30 \\
\hline $\begin{array}{l}\text { Age receiving } \\
\text { AS-diagnosis }\end{array}$ & 14 & $?$ & 10 & 24 & 5 & 24 & 29 & 24 & 18 & 18 & 22 & 29 & 19 & 23 \\
\hline Other diagnosis & $\mathrm{Y}$ & $\mathrm{Y}$ & $\mathrm{N}$ & $\mathrm{N}$ & $\mathrm{N}$ & $\mathrm{Y}$ & $\mathrm{N}$ & $\mathrm{Y}$ & $\mathrm{Y}$ & $\mathrm{Y}$ & $\mathrm{Y}$ & $\mathrm{N}$ & $\mathrm{Y}$ & $\mathrm{Y}$ \\
\hline Attended the IT-track & 2012 & 2012 & 2013 & 2013 & 2014 & 2012 & 2014 & 2014 & 2014 & 2013 & 2014 & 2013 & 2014 & 2013 \\
\hline
\end{tabular}

Source: own

Thirteen of the interviews were recorded and transcribed, while notes were taken during one of the interviews since the student did not want to be recorded. The research interviews were semi-structured, lifeworld interviews (Kvale and Brinkmann, 2009; Lantz, 1993). An interview guide with seven open-ended questions was used together with possible follow-up questions. Notwithstanding this, the interviews were open, since the respondents' answers influenced the direction that the interviews took (Hammersley and Atkinson, 2007; Hydén and Bülow, 2003). A focus group interview (Halkier, 2008; Hydén and Bülow, 2003) was conducted with the staff of the IT-track and lasted 80 minutes. A follow up interview was conducted in autumn 2016 with the occupational therapist/ coordinator and lasted 60 minutes. Both researchers were present on these two occasions. The authors translated the transcripts from Swedish to English and a professional translator then checked the accuracy of the translation.

\section{Interpretation of the data}

The data is rich and distinctive since information can be found on two different levels. The first level relates to the researcher who experienced, interpreted, and documented what took place at the IT-track. The second level relates to the participants themselves, who 
described their experience in their own words, (the content of which was later interpreted by the researcher). This combination of two levels of data enables an authentic interpretation of the students' experiences (see Hedegaard, Ahl, Rovio-Johansson and Siouta, 2014; Hedegaard, Rovio-Johansson and Siouta, 2013; Hugo, 2007, 2013).

With the help of many citations that express the students' own words, our intention is to provide a rich description of the students' experience of the IT-track. As we interpret the field notes that were made during the observations, we describe what emerges in the collected data material. According to Kvale and Brinkman (2009), it is of importance that we describe what takes place as accurately and completely as possible. Bengtsson (2005) argues that the empirical material should be expressed in its own terms, within the framework of the question that is being answered.

A continuous hermeneutic interpretation (Van Manen, 1990) of the observations and interviews took place during the autumn of 2014, during both the actual data collection process and during the processing and analysis of the collected material. This meant that the interpretation was not only limited to the transcribed interviews or the field notes, rather it was an on-going interpretation that started when we first attended the IT-track. The next step was to formalize the interpretation through a qualitative content analysis with a focus on the latent content, where we interpreted the empirical material and created themes that described the central content (Krippendorff, 2004). The analysis comprised three steps inspired by Creswell (2014). Step 1: The material was transcribed and a first read-through was carried out. Step 2: A more thorough read-through of the transcribed material. This read-through generated an overview of the material and contributed an insight into the meaning that appeared in the material. Step 3: The material was coded based on keywords and statements. Thereafter, we constructed six central themes.

\section{Ethical considerations}

All of the participants were informed about the purpose of the study and gave their consent to be included in the study. However, one student did not want to be recorded during the interview, so we took notes instead. The participants provided written approval for the use of empirical data in future publications. The respondents' right to privacy meant that they were treated and described confidentially. It is, however, not possible to fully avoid the possibility that people in such a distinct group might be able to identify each other. In summary, in the observations and interviews with students and staff we followed the ethical requirements of the Humanities and Social Sciences (Swedish Research Council, 2002, 2005).

\section{RESULTS}

In the result section, the six themes that emerged from content analysis are presented: Adjustments in the work environment; Structure and clarity in the work; To be seen, acknowledged and understood; Structure in everyday life; Better social functioning and Extended horizons of possibility. 


\section{Adjustments in the work environment}

Some adjustments were identified in the work environment. The IT-track students had a private entrance to the school building and they also had specially-adapted premises such as individual work places with their own computers, flexible work hours and small study groups. During the student interviews, we noted the importance of the adaptations in the work environment which were tailored to suit the students' needs. Several students reported that they found it difficult to concentrate if there was a lot of noise in the environment, and thus highlighted the importance of having their own work place. One of the students described it as follows:

You have your own work place... it's great... instead of having, a computer lab work while sitting in a large computer room... I find it very hard to concentrate when there are lots of people around. (S7)

In the IT-track, this entailed that all of the students either had their own room or the opportunity to screen off their work place completely with movable screens. They could choose for themselves whether they wanted to have contact with other students or not. The students wanted to be left alone during much of the time when they worked, but they did not want to be alone. One of the students said:

I'm like that... I hate people, it's the worst thing I know [...] I keep to myself and never take any breaks or anything, I rather sit at the computer and there I am. Is anybody talking to me, then it's obvious that I'm talking to them... but I would never be able to begin a discussion [...] I think it's a blast to sit here and work with programming and even cozier to sit when there's not a bastard left [...] silent everywhere... just me... then you get a calm feeling in the body that is unbelievable. (S2)

\section{Structure and clarity in the work}

Other adjustments identified were that the students had individual study plans and that they encountered a clear and structured educational training with the same format each day and each week. The daily lectures were 25-50 minutes long and were always linked to laboratory work based on the content of the lectures. It was crucial for these students that they had teachers who provided structure to their lessons and were very clear in describing the tasks that the students were expected to perform. Being engaged with several different tasks at the same time often created problems for the students. It was best that a teacher distributed one task at a time so that the students could focus on that task until it was completed, and then be assigned a new task. This scheduling of tasks was a success factor in the IT-track where the students usually completed one assigned task at a time within the framework of one course. Students did not start the next course until the previous course was completed. Several of the students described one of the problems they experienced with elementary school as being that they had to take many different 
subjects at the same time. Several students achieved significantly better study results in upper secondary school when they had a mentor who was able to make adjustments to their study schedule so that only one or two subjects were taken at the same time. The structure of the course schedule in the IT-track was appreciated by the students and one of them specifically reported this:

What I like here is how we have only two courses and not on the same day... On Monday, Tuesday and Wednesday, it's an upper secondary school course, On Thursdays, I have a University course and on late Friday's, it's mostly the University course. But if you're behind in the upper secondary school course... well then it's one of those days that you just work up. This structure is important for me... then it's not too many different subjects that you have to keep track of. (S12)

\section{To be seen, acknowledged, and understood}

One of the most important aspects of the educational program was the students' experience of being in a social context where they felt appreciated by others. Whilst they were enrolled in the IT-track, the students told us that they felt appreciated and that their confidence had grown. The teachers were described as the most important support function within the program. Experiencing trust, being seen and acknowledged, and being treated with respect for who they were, were the most prominent aspects. One of the students said: "When you came here, it was great because they know exactly how they'll handle us and they're good people" (S9). Another student reported: "I've been treated better here than I've ever been in any other place" (S11). One student told us that the teachers' attitude made them feel calm and welcome:

He gets me feeling serene here. He gets me feeling calm. And he gets me to feel welcome [...] and it's thanks to that he's there and he's himself and he's as calm as possible, and he gets me to feel calm. You get, when you're near him, calm energy and then you feel calm... and it's probably the greatest support he has given me (S1).

The IT-track gave the students the opportunity to experience participation and alignment. According to 13 of the students, the IT-track was fully adapted to their needs and circumstances, and they experienced being part of a meaningful and participatory social context for the first time in their lives.

I'll be honest with you, I appreciate it really much [...] For it's really good stuff that they've done here and really puts adults with Asperger in focus and try to help our needs [...] it's tricky when there are exactly the same requirements for all people and it should be done in the exact same order [...] It's so damn fun here... it's probably why I come back every day just because I know that here I'm surrounded by cool teachers and disturbed students (laughter) (S2). 
All the students were happy with the attitudes displayed by their teachers:

This is the way I want it, I want it at a level where the teacher trusts that I know what I'm doing. I understand my own talents and limitations. (S1)

\section{Structure in everyday life}

Because of their participation in the IT-track and the adaptations mentioned earlier, the students reported that they felt better and that their need for home support and medication had decreased. Five of the students reported that they had learned how to structure their time better and thereby manage to do more in their everyday life outside school:

Before I started here, I had great need for home support... when I started here, I decided that I didn't want it. The result was that I clean, wash, and do the dishes. Those things have never worked before [...] I have regained control of my life (S1).

Now there's a structure [...] it feels damn nice because I've never had a routine in my life. That's something people with Asperger have a problem with... getting routines. It feels damn good to finally have found a routine on something... that works... that's what is so incredible (S2).

Five students stated that they had learned to take more responsibility for their studies and were working more independently now. Thirteen students also told us that their confidence had progressively increased and that they had learned to take on more challenges and tasks: "The biggest problem when you got here... you didn't try yourself... but I've learned a sensible thing when I've been here... and that's try yourself, you will make it" (S2).

\section{Better social functioning}

The students described various aspects of their learning. Through social learning, they could develop social skills that allowed them to function better with others. For instance, all of the students reported that they felt comfortable with their classmates in the IT-track. However, feeling comfortable with their classmates did not necessarily entail that they talked to each other. Twelve students preferred to be alone and work by themselves, and four students did not know the names of their classmates. Eight students spoke about a lack of interest in spending time with the others, but at the same time, they felt that they did get along well with each other and they felt respected by their classmates.

If I'll be honest, I've hardly spoken to that many. Well I'm not very social... but when you meet others when you sit in a room like this, it's very good I think... and when we sit in our cubicles, there is no problem either (S8).

I've not talked to many of my classmates so I don't remember any names (laughter). But the ones I have talked to have been very nice (S13). 
However, eight students reported that they had become more interested in socializing with others as the IT-track progressed. Three students even reported that they lived together in an apartment.

It has also given a lot socially [...] in a regular school that I went to before, it was marked that I was special... I don't connect with the people. But since we've come to this school aware that people do not connect... then we've not had any panic regarding socializing. We were three that lived together... I still live with one from this school, and then I'm dating one of the others. It works great... it's things like that you don't think should work, because you have Asperger and know what limitations you have. But since it has become a more humble social constellation, it becomes much easier to not feel any social pressure (S1).

This interest in socializing with each other is described by $\mathrm{S} 1$ as the most important learning experience from the IT-track. The teachers' attitude toward, interest in, and commitment to the students resulted in the students' developing empathy for each other. A special social safety net had been built for some of the students:

We had a guy who was about to kill himself last year... and then... we do have some small groups that keep tabs on each other... we are four people who have keys to each other [...] Don't think that we'd come up with this if we'd not seen what a difference it made. [...] It's one of the major important stuff that the teacher has helped with. Before, we always thought: I can do better by myself. We're several who have been able to stop with the home support because we motivate each other instead (S1).

Moreover, seven students said that they regularly met at a gaming association during their leisure time. For four of these students, this was the first time in many years that they had enjoyed social interaction:

When I started this, I didn't even wanted to talk [...] I've socialized a little bit now... played together and so... card games actually. He (one of the students) is the gaming organizer here downtown... so I've been there (S11).

The students also told us about the additional social skills that they had learned, such as asking for help, talking to groups, and structuring their everyday life. They stated that they had never asked teachers or classmates for help before their participation in the program; but after some time in the program, they had learned to ask their classmates for help. Six students also stated that they had learned to work together in solving different tasks:

[...] what I like here is if you have some problems with anything and you don't really know how to solve it... then ask someone else who's in the same course... then you start to think together about how to solve the problem... I think it's 
important to be able to do so because it's how to do it out in the workplace [...] To dare asking for help is a good thing to be able to (S12).

Speaking in front of others was a big challenge for most of the students in the IT-track. Five students said that during their stay in the IT-track, they had learned to dare to talk to their fellow students, even in front of the class when between 5 and 10 other students were present: "It's something I also learned... talking to the group... I couldn't before because it was really tough and it's still really hard, but after a while you felt that they're almost listening" (S2).

\section{Extended horizons of possibility}

Twelve students in the IT-track told us that they had experienced difficulties in finding a job after leaving upper secondary school. Moreover, only four of them were eligible for higher education at the time. Three students had continued with their studies, either in adult education or in the Swedish folk high school system. Two students had started university courses from which they had subsequently dropped out. Six students had been gainfully employed but only for short and irregular periods. Five of the students said that after they had left upper secondary school, they had not really done anything organized. Four of them sat at home hardly meeting other people, which led to a feeling of marginalization and exclusion from society. For many of the students, attending the IT-track resulted in breaking a long period of isolation:

I haven't had a real job... it's starting to feel a little awkward when you're thirty and haven't really found your place (S14).

I didn't really know what to do because I didn't finish Upper Secondary school... I couldn't cope with the last year there... and then it became that I sat at home and did nothing (S13).

Five of the students also spoke of previous long-term depression:

Then I got my bad period of depression... so I was out of a job... ended up in a pre-stabilizing and then "climb up" process... that went on until this day... it was a long time where I really didn't do anything... I've had contacts with a psychologist and then I ended up here eventually (S12).

Ten of the students stated that attending the IT-track was 'a new start in life': "It's probably the best thing that has happened to me" (S12). Another student said that he had developed a routine and felt that there was finally something happening in his life:

I've started to get going again, much better... I get a lot more done... it's very nice [...] You start to get some routines again... start coming back ... it works better with the circadian rhythm as well [...] I'd been sick for a long time ... before I got my examination. Then when the sick leave ran out, I went for some time there [...] Now I have some routines and begin to get back working and learning to use the working memory again (S7). 
By attending the IT-track, the students developed a sense of a more meaningful existence in which they felt more involved as part of a social context. Thirteen students reported that they had developed new hope in life and they looked more positively toward the future. "I was very down when I started here but now I'm ready again ... everything seems to resolve itself... maybe I can even have a job within a few months," said S11. Another student told us that the future did not feel that impossible anymore after attending the IT-track: "It's better than I thought [...] I went from thinking I'll probably get sickness benefits to considering becoming an engineer. Only to dare thinking that it doesn't need to be as it always has been before... I could do something with my life [...] The future doesn't seem impossible anymore" (S1). Overall, the IT-track led to a situation where the students could replace a lack of confidence and poor self-esteem with a greater confidence in themselves, their skills, and general abilities.

The follow-up interview with the coordinator in autumn 2016 showed that twelve of the students had completed the IT-track two years after the study in 2014. At that time, two of the students were still attending the IT-track. Of the twelve students who had completed the IT-track, five had found jobs and three held internship places. Of the five students who had found a job, three held full time paid jobs in 2016, and two had jobs partly funded by the government. Four of the students had not made any transitions to employment after they left the IT-track. These outcomes are described in Table 2.

Table 2: Overview of student achievement, October 2016

\begin{tabular}{|l|c|c|c|c|c|c|c|c|c|c|c|c|c|c|}
\hline Respondents & 1 & 2 & 3 & 4 & 5 & 6 & 7 & 8 & 9 & 10 & 11 & 12 & 13 & 14 \\
\hline $\begin{array}{l}\text { Completion of the } \\
\text { IT-track }\end{array}$ & $\mathrm{Y}$ & $\mathrm{Y}$ & $\mathrm{Y}$ & $\mathrm{Y}$ & $\mathrm{Y}$ & $\mathrm{Y}$ & $\mathrm{Y}$ & $\mathrm{Y}$ & $\mathrm{Y}$ & $\mathrm{Y}$ & $\mathrm{Y}$ & $\mathrm{Y}$ & $\mathrm{N}$ & $\mathrm{N}$ \\
\hline In work/employment & $\mathrm{N}$ & $\mathrm{Y}$ & $\mathrm{N}$ & $\mathrm{N}$ & $\mathrm{N}$ & $\mathrm{Y}$ & $\mathrm{Y}$ & $\mathrm{N}$ & $\mathrm{Y}$ & $\mathrm{N}$ & $\mathrm{Y}$ & $\mathrm{N}$ & - & - \\
\hline In internship & & & & $\mathrm{X}$ & $\mathrm{X}$ & & & $\mathrm{X}$ & & & & & - & - \\
\hline
\end{tabular}

Source: own

\section{DISCUSSION AND IMPLICATIONS}

Previous research has highlighted the difficulties that people associated with high-functioning autism face as they try to enter the labour market (Hendricks, 2010; Krieger et al., 2012; Larsson Abbad, 2007; Roy, Prox-Vagedes, Ohlmeier and Dillo, 2015). In this study, five of the students were gainfully employed two years after the study was conducted, which has both human/individual and economic consequences. According to calculations by Nilsson and Wadeskog (2012), these employments could realize societal savings of approximately SEK 34 million (approximately USD 4.5 million). In addition, we found other habilitative effects from the IT-track:

(a) the students' need for home support and medication decreased

(b) the students developed their ability to empathize with others 
(c) they began to function better socially with other students and teachers,

(d) the students stated in the interviews that they had learned to ask for help,

(e) talk in front of a group, and

(f) socialize with each other outside the school.

These social skills (b-f) may help to increase the possibilities for the students to obtain jobs.

The exclusion and marginalization of people associated with high-functioning autism is often linked to such individuals not having their special needs met in school (Attwood, 2008; Jackson, 2011; Simmeborn Fleischer, 2012). This failure to meet their needs is especially apparent regarding the lack of specially-designed support functions, with respect to both formal and informal learning (Adolfsson and Simmeborn Fleischer, 2013; Anthony and Unger, 1991; Börnfelt, 2014; Giarelli and Fisher, 2013; Mowbray, 2000; Unger et al., 1991). We note that a clear and continuous structure that includes short lectures followed by practical application work and access to individual workplaces where the students can work alone was a favorable arrangement for this student group. Of the support functions that were available in the IT-track, the students reported that the teachers constituted the most important support function. In particular, the students described the teachers' ability to create a safe and meaningful learning environment in which the students felt that they were seen, acknowledged, and understood. In other words, the teachers in the IT-track contributed to a definite increase in the students' sense of comprehensibility, manageability, and meaningfulness (Antonovsky, 1987) through the relationships they built with the students (Aspelin, 2012; Johnson, 2008). The teachers' social competence in an interpersonal relation to create a feeling of being taken seriously and of being safe among other students is described by van Manen (1992) as 'the tact of teaching'. This means that the teacher perceives and understands the importance of meeting the students' desires and curiosity by being able to read their physical state. In traditional upper secondary education in Sweden, students usually meet at least 6-8 teachers. In the IT-track the students only meet two teachers, which increases the possibility of developing meaningful and safe relations. One risk associated with extending the students' horizons of possibilities is that those students who did not make any transitions to employment after the IT-track may relapse into solitude and isolation from society, as their optimism for the future is shattered. Therefore, it is important that this type of educational program also include a safety net with subsequent support functions for those who do not get jobs or internships in a timely manner after the program is completed.

\section{Limitations and Future research}

The study has some limitations, for instance concerning the student group. The students in this study were carefully selected by the staff in the IT-track. This meant that the students had been identified as having a strong interest in IT and a desire to work in the field, as well as having the capacity to learn the content of the different courses. Thus, it is reasonable to believe that the level of motivation within this group of students was high to 
begin with, and their ability to complete the education was good. It is important to keep in mind that other student groups might not be as high-functioning as this group and that the selection process prior to the start of the IT-track influenced the results. Future research should therefore examine other educational programs directed toward a broader selection of people associated with high-functioning autism. Another limitation is that this study only concerns the educational part, the environment in which the habilitation is occurring. We have not studied how the habilitated students function in a work environment. Future research should therefore investigate the internship and work places where some of the students now work in order to examine the sustainability of the habilitating effects. It would also be of importance to study the adjustments made in these work and internship environments, and the student experiences thereof.

\section{Implications for practice}

The support and understanding of the students that was shown by the staff in the IT-track is difficult to find in the open labour market. Individuals associated with high-functioning autism are usually described as having the potential to develop expertise in the areas they are interested in (Volkmar, Klin and McPartlanc, 2014). For employers, the challenge is to make environmental adjustments to create conditions where individuals associated with high-functioning autism are given the chance to become high-performing within their areas of interest. In the IT-track we found three aspects that were important to the students; a) individually adjusted work places, b) structure and clarity in the work, and c) a teacher who understands the individuals. These aspects can also be useful for employers when they try to create an inclusive work environment for individuals associated with high-functioning autism.

\section{CONCLUSIONS}

The environment in the IT-track provided the students with supportive conditions to succeed in their studies and in their social development. Hence, the conditions surrounding the individual(s) needed to be 'normalized', and not the individual(s) (see Nirje, 1994 on the 'normalization principle'). One of the main findings of the study was the social learning, in terms of the development of social and emotional skills, that took place. Due to the symptoms attributed to individuals associated with high-functioning autism (problems in the areas of socialization, communication, and imagination), and the fact that the diagnosis is often described as 'static' (Helles, Wallinius, Gillberg and Billstedt, 2016), it is noteworthy how much the students learned in these 'problem' areas during their time in the IT-track. 


\section{REFERENCES}

Adolfsson, M. and Simmeborn Fleischer, A. (2013). Applying the ICF to identify requirements for students with Asperger syndrome in higher education. Developmental Neurorehabilitation, 18(3), 190-202.

Ahrne, G., Roman, C. and Franzén, M. (2013). Det sociala landskapet: en sociologisk beskrivning av Sverige från 1950-talet till början av 2000-talet. Göteborg: Bokförlaget Korpen.

Andersson, T. (2006). Asperger syndrom och liknande autismtillstånd hos vuxna: en grundbok. Göteborg: Ander utbildning och förlag.

Andersson, T. (2008). Asperger, ADHD och arbete. Göteborg: Andet utbildning och förlag.

Anthony, W. A. and Unger, K. V. (1991). Supported education: an additional program resource for young adults with long term mental illness. Community Mental Health Journal, 27(2), 145-156.

Antonovsky, A. (1987). Unraveling the Mystery of Health - How People Manage Stress and Stay Well. San Francisco: Jossey-Bass Publishers.

Arbetsförmedlingen. (2015). Arbetsförmedlingens Aterrapportering 2015. En strategi för genomförandet av funktionshinderpolitiken 2011-2016. Stockholm: Arbetsförmedlingen.

Aspelin, J. (2012). How Do Relationships Influence Student Achievement? Understanding Student Performance from a General, Social Psychological Standpoint. International Studies in Sociology of Education 22(1), 41-56.

Attwood, T. (2008). The Complete Guide to Asperger's Syndrome. London: Jessica Kingsley Publishers.

Bandura, A. (1982). Self-Efficacy Mechanism in Human Agenda. American Psychologist, 37(2), 122-147.

Bengtsson, J. (2005). En livsvärldsansats för pedagogisk forskning. In J. Bengtsson (Ed.), Med livsvärlden som grund. Bidrag till utvecklandet av en livsvärldsfenomenologisk ansats i pedagogisk forskning (pp. 9-58). Lund: Studentlitteratur.

Börnfelt, P.-O. (2014). Individual Placement and Support. Jönköping: FoURUM-Regionsförbundet i Jönköpings län.

Creswell, J. C. (2014). Research Design: Qualitative, Quantitative, and Mixed Methods Approaches. Thousand Oaks: Sage.

Cron, W. L., Slocum, J. W., Vandevalle, D. and Fu, Q. (2005). The Role of Goal Orientation on Negative Emotions and Goal Setting When Initial Performance Falls Short of One's Performance Goal. Human performance, 18(1), 55-80.

Giarelli, E. and Fisher, K. (2013). Transition to community by adolescents with Asperger syndrome: Staying afloat in a sea change. Disability and Health Journal, 6(3), 227-235.

Goodley, D. (2017). Disability Studies. An Interdisciplinary Introduction. Thousand Oaks: SAGE.

Halkier, B. (2008). Fokusgrupper. Frederiksberg: Samfundslitteratur.

Hammersley, M. and Atkinson, P. (2007). Ethnography - principles in practice. London and New York: Routledge.

Hedegaard, J., Ahl, H., Rovio-Johansson, A. and Siouta, E. (2014). Gendered communicative construction of patients in consultation settings. Women \& Health, 54(6), 513-529.

Hedegaard, J., Rovio-Johansson, A. and Siouta, E. (2013). Communicative Construction of Native versus Non-Native Swedish Speaking Patients in Consultation Settings. Scandinavian Journal of Public Administration, 17(4), 21-47.

Helles, A., Wallinius, M. I., Gillberg, C., Gillberg, C. and Billstedt, E. (2016). Asperger syndrome in childhood - personality dimensions in adult life: temperament, character and outcome trajectories. British Journal of Psychiatry, 2(3), 210-216. 
Hendricks, D. (2010). Employment and adults with autism spectrum disorder: Challenges and strategies for success. Journal of Vocational Rehabilitation, 32(2), 125-134.

Houtenville, A. J., Brucker, D. L. and Lauer, E. A. (2016). Annual compendium of disability statistics, 2015. New Hampshire: Institute on Disabilities.

Hugo, M. (2007). Liv och lärande i gymnasieskolan. En studie om elevers och lärares erfarenheter $i$ en liten grupp på gymnasieskolans individuella program. Jönköping: Jönköping University Press.

Hugo, M. (2013). Meningsfullt lärande i skolverksamheten på särskilda ungdomshem (Vol. 2013:1). Stockholm: Statens institutionsstyrelse.

Hydén, L. C. and Bülow, P. H. (2003). Who's talking: drawing conclusions from focus groups-some methodological considerations. International Journal of Social Research Methodology, 6(4), 305-321.

Jackson, L. (2011). Miffon, nördar och Aspergers syndrom. Lund: Studentlitteratur.

Johnson, B. (2008). Teacher-student relationships which promote resilience at school: a micro-level analysis of students' views. British Journal of Guidance \& Counseling. 36(4), 385-398.

Krieger, B., Kinébanian, A., Prodinger, B. and Heigl, F. (2012). Becoming a member of the work force: perceptions of adults with Asperger Syndrome. Work (Reading, Mass.), 43(2), 141-157.

Krippendorff, K. (2004). Content analysis: an introduction to its methodology. Thousand Oaks: Sage.

Kvale, S. and Brinkmann, S. (2009). Den kvalitativa forskningsintervjun. Lund: Studentlitteratur.

Lang, R. (2009). The United Nations Convention on the right and dignities for persons with disability: A panacea for ending disability discrimination? ALTER - European Journal of Disability Research, 3(3), 266-285.

Lantz, A. (1993). Intervjumetodik. Lund: Studentlitteratur.

Larsson Abbad, G. (2007). “Aspergern, det är jag” - En intervjustudie om att leva med Asperger Syndrom. Linköping: Lidköpings Universitet: Institutionen för beteendevetenskap och lärande.

Lindqvist, R. (2012). Funktionshindrade i välfärdssamhället. Malmö: Gleerups.

Lozic, V. (2014). Inclusion Through Exclusion: Teachers' Perspectives on Teaching Students with Autism. Cypriot Journal of Educational Sciences, 9(1), 3-13.

Meekosha, H. and Soldatic, K. (2011). Human Rights and the Global South: the case of disability. Third World Quarterly, 32(8), 1383-1397.

Mowbray, C. (2000). Rehab Rounds: The Michigan Supported Education Program. Psychiatric Services, 51(11), 1355-1357.

Nilsson, I. and Wadeskog, A. (2012). Utanförskapets ekonomiska sociotoper. Socioekonomisk analys på stadsdelsnivå inom ramen för Healthy Cities. Karlshäll: SEE AB.

Nirje, B. (1994). The Normalization Principle and Its Human Management Implications. The International Social Role Valorization Journal, 1(2), 19-23.

Priestley, M. (2007). In search of European disability policy: Between national and global. ALTER - European Journal of Disability Research, 1(1), 61-74.

Roux, A. M., Shattuck, P. T., Cooper, B. P., Anderson, K. A., Wagner, M. and Narendorf, S. C. (2013). Postsecondary employment experiences among young adults with an autism spectrum disorder. Journal of the American Academy of Child and Adolescent Psychiatry, 52(9), 931-939.

Roy, M., Prox-Vagedes, V., Ohlmeier, M. D. and Dillo, W. (2015). Beyond childhood: Psychiatric comorbidities and social background of adults with Asperger syndrome. Psychiatria Danubina, 27(1), 50-59.

Simmeborn Fleischer, A. (2012). Support to students with Asperger syndrome in higher education--the perspectives of three relatives and three coordinators. International Journal of Rehabilitation Research, 35(1), 54-61. 
Socialstyrelsen. (2012). Sysselsättning för personer med psykisk funktionsnedsättning. Utvärdering av statsbidrag under åren 2009-2011. Stockholm: Socialstyrelsen.

Statistiska Centralbyrån. (2015). Situationen på arbetsmarknaden för personer med funktionsnedsättning 2014. Stockholm: Statistiska Centralbyrån.

Swedish Research Council. (2002). Forskningsetiska principer inom humanistisk-samhällsvetenskaplig forskning. Stockholm: Swedish Research Council.

Swedish Research Council. (2005). Särskilda anvisningar för utbildningsvetenskap. Stockholm: Swedish Research Council.

Unger, K. V., Anthony, W. A., Sciarappa, K. and Rogers, E. S. (1991). A supported education program for young adults with long-term mental illness. Hospital \& Community Psychiatry, 42(8), 838-842.

Van Manen, M. (1990). Researching Lived Experience. Michigan: Edwards Brothers.

Van Manen, M. (1992). The Tact of Teaching. The Meaning of Pedagogical Thoughtfulness. London, Ontario: The Althouse Press.

Volkmar, F. R., Klin, A. and McPartland, J. C. (2014). Asperger Syndrome: An Overview. In J. C. McPartland., A. Klin. and F. R. Volkmar (Ed.), Asperger Syndrome. Assessing and Treating High-Functioning Autism Spectrum Disorders (pp. 1-43). New York: The Guilford Press.

Wing, L. (1981). Asperger's syndrome: a clinical account. Psychological Medicine, 11(1), 115-129.

World Health Organization \& The World Bank. (2011). World report on diability. Genéve: World Health Organization. 